\title{
Article
}

\section{Genetic Variation and Phenotypic Response of 15 Sweet Corn (Zea mays L.) Hybrids to Population Density}

\author{
Adrienne C. Shelton ${ }^{1,2}$ and William F. Tracy ${ }^{1,2, *}$
}

1 Nelson Institute for Environmental Studies, University of Wisconsin-Madison, Madison, WI 53706, USA; E-Mail: acshelton@wisc.edu

2 Department of Agronomy, College of Agricultural and Life Sciences, University of Wisconsin-Madison, Madison, WI 53706, USA

* Author to whom correspondence should be addressed; E-Mail: wftracy@wisc.edu; Tel.: +1-608-262-2587; Fax: +1-608-262-5217.

Received: 9 May 2013; in revised form: 20 May 2013 / Accepted: 28 May 2013 /

Published: 3 June 2013

\begin{abstract}
Planting sweet corn at higher densities may increase the canopy cover, reducing light transmission to the understory and suppressing weed growth. High planting densities can also negatively impact the crop, however, by decreasing ear size and overall yield. The objective of this study was to determine the potential for increased density tolerance of 15 sweet corn hybrids by estimating the general combining ability (GCA) and specific combining ability (SCA) for traits of interest. In 2010 and 2011, a half-diallel of six historic sweet corn inbreds was evaluated in a split-block randomized complete block design in four Wisconsin environments, with four replicates in each environment. Hybrids were planted at a low density of 29,936 plants ha ${ }^{-1}$, a medium density of 63,615 plants ha ${ }^{-1}$, and a high density of 97,293 plants $\mathrm{ha}^{-1}$. Significant differences between hybrids were found for phenomorphological traits and ear characteristics. Inbreds C68, C40 and Ia5125 produced the progeny most tolerant of the highest population density. Among these genotypes, tolerance to high density is a heritable trait, indicating the feasibility of breeding sweet corn for density tolerance and potential weed competitiveness.
\end{abstract}

Keywords: Zea mays; sweet corn; density tolerance; weed competition 


\section{Introduction}

Organic agriculture has grown at an unprecedented rate in the past decade. Between 2000 and 2008, certified organic farmland in the United States has more than doubled, from 700,000 hectares to 1.9 million hectares [1]. This small but vibrant sector of the food system has also seen steady growth in consumer sales each year. In 2010, organic food sales totaled \$26.7 billion, a 7.7\% increase from 2009 [2]. A growing body of literature indicates that organic agriculture positively impacts the environment through non-renewable resource conservation and enhanced biodiversity $[3,4]$. These indices of farmer interest, consumer demand and environmental stewardship justify continued exploration of best organic practices by the agricultural research community.

One area of necessary study involves weed management in organic systems. Weeds negatively impact crop growth by competing for limited environmental resources, harboring insect pests and serving as alternate hosts for plant pathogens. In the absence of chemical suppressants, organic farmers often utilize increased tillage and cultivation as one method of weed control. However, mechanical weed control is usually not sufficient to reduce weed populations to levels below the economic threshold [5]. In addition, intensive soil disturbance can accelerate loss of soil organic matter, destroy soil aggregates and increase soil erosion [6,7]. Organic farmers require effective alternative weed control methods, including crops bred to tolerate higher planting densities and thus competitively suppress weeds [8,9].

In the United States and in Wisconsin, sweet corn is a valuable vegetable crop that deserves such attention. Grown for both the fresh and processing markets, 266,250 hectares of sweet corn were planted in the United States in 2010, occupying the largest area of any vegetable crop [10]. Over 50\% of all sweet corn fields in the north central region (Wisconsin, Minnesota and Illinois) suffer some amount of yield loss due to weed interference [11]. A study of 25 sweet corn hybrids found that wild-proso millet (Panicum miliaceum L.) reduced ear number by $11-98 \%$ and ear mass by $24-82 \%$ depending on the hybrid [12].

Sweet corn growers are currently planting an average of 56,000 plants $\mathrm{ha}^{-1}$ [13]. At higher plant densities, a sweet corn field is more likely to form a closed canopy to effectively eliminate light penetration to the soil and suppress weed growth. Analysis of field corn breeding over the past 80 years proves the success of this method. A well-known series of experiments, known as the "Era hybrid studies", demonstrates the continuous gain in yield among field corn hybrids in Iowa from the early 1930s through 2001 [14-16]. Comparisons of hybrids by decade show a linear increase in yield gains among field corn hybrids by era, with the newest hybrids producing the highest yields. The increase in yield results from the ability of the newest hybrids to continue to produce an ear on every plant, while the older hybrids tend to have barren plants, or plants with few kernels, at the highest densities.

While not directly breeding for weed suppression, one of the effects of the increased density tolerance of field corn is a rapidly closing canopy, which greatly reduces sunlight in the understory. An experiment conducted by McLachlan et al. [17] comparing the effect of two field corn planting densities $\left(25,000\right.$ plants $\mathrm{ha}^{-1}$ and 50,000 plants $\left.\mathrm{ha}^{-1}\right)$ showed that the photosynthetic photon flux density through the crop canopy declined with increased planting density. Another study using three field corn planting densities (40,000, 70,000 and 100,000 plants ha ${ }^{-1}$ ) and three weed densities resulted in up to a $50 \%$ weed biomass reduction between the low and high field corn densities [18]. Similar 
results have been documented in other crop species such as wheat (Triticum aestivum), barley (Hordeum vulgare), and safflower (Carthamus tinctorius) [19-21].

One area of concern when increasing the crop density is the effect on ear characteristics. While a dense crop canopy may be an effective weed management tool, it will be useless to the farmer if the corn plants are barren or produce ears that are unusable. A study conducted in the 1960s found that an increase in sweet corn planting density from 11,700 plants ha ${ }^{-1}$ to 17,700 plants $\mathrm{ha}^{-1}$ decreased ear weight by $6 \%$ [22]. Rogers and Lomman [23] also concluded that increasing the number of sweet corn plants per square meter reduced ear weight and percent kernel fill. In a much more recent study, Williams [13] evaluated sweet corn hybrids grown at four densities (43,000 plants ha ${ }^{-1}, 57,400$ plants ha $^{-1}$, 71,700 plants $\mathrm{ha}^{-1}$, and 86,000 plants $\mathrm{ha}^{-1}$ ) and found that filled ear length and recovery declined with increasing population density. Recovery, a metric used in the sweet corn processing industry, quantifies the cut kernel weight relative to the green ear weight. Thus, it is crucial to be able to identify germplasm that can withstand high planting densities without compromising yield and quality.

The purpose of this study is to examine the inheritance of traits associated with density tolerance in sweet corn. Fifteen sweet corn hybrids were developed from a half-diallel of six historic inbreds, estimating the general combining ability (GCA) and specific combining ability (SCA) for traits of interest. As defined by Sprague and Tatum [24], GCA refers to the "average performance of a line in hybrid combination", and SCA represents "those cases in which certain combinations do relatively better or worse than would be expected on the basis of the average performance of the lines involved". These results will enable future breeding to focus on improving sweet corn for increased density tolerance and weed suppressive ability.

\section{Results and Discussion}

\subsection{Hybrid Evaluation}

Results demonstrated that there were significant differences for phenomorphological traits and ear characteristics measured across 15 hybrids developed in the half-diallel mating design. The following sources of variation were significant $(p \leq 0.05)$ for all traits: environment, density, hybrid, and hybrid-by-environment interaction (Table 1). In addition, significant environment-by-density effects existed for yield, ear height, wet weight, dry weight, ear length, ears $\mathrm{ha}^{-1}$ and moisture. Hybrid-by-density interaction was significant for all traits except for kernel size. All traits with significant hybrid effects and equal variances were further analyzed for combing ability, with significant GCA effects found in all traits, and significant SCA effects found in all cases except tiller number (Table 1). Spearman rank correlations indicated that traits could be pooled across all environments, with the exception of yield, dry weight, ear length, kernel depth and ears ha ${ }^{-1}$.

Averaged across all environments (2010 and 2011 growing seasons in West Madison and Arlington, Wisconsin) the least square mean estimates for plant height ranged from the shortest hybrid, P51 $\times$ P39, at $207.4 \mathrm{~cm}$, to the tallest hybrid, Ia5125 $\times$ C68, at $267.9 \mathrm{~cm}$ (Table 2). Ear height was lowest on P39 $\times$ IL101t at $71.1 \mathrm{~cm}$, and highest on Ia5125 $\times$ C68 at $116.0 \mathrm{~cm}$. Ia5125 $\times$ C68 had only 0.5 tillers plant $^{-1}$, while P39 $\times$ IL101t had 2.8 tillers plant $^{-1}$. The hybrid with the lightest wet weight ear ${ }^{-1}$ was P51 $\times$ P39 at $126.5 \mathrm{~g}$, and the heaviest was C68 $\times$ C40 at $247.7 \mathrm{~g}$. The narrowest ears were found 
on P51 $\times$ P39 at $33.8 \mathrm{~mm}$, and the widest ears were from Ia5125 $\times$ C68 at $42.4 \mathrm{~mm}$. At harvest, IL101t $\times$ Ia5125 dried down to $45 \%$ moisture, and C68 $\times$ C40 retained the most water at 59\% moisture. These same two hybrids were the earliest and latest maturing, respectively, across the 2010 and 2011 West Madison, WI environments (data not shown).

For the traits that could not be pooled across all environments, most were analyzed separately between 2010 and 2011, while pooling the locations within years. In both the 2010 and 2011 environments, P51 $\times$ P39 had the lowest yields at 0.86 and 2.41 metric tons ha ${ }^{-1}$, respectively (Table 3). Ia5125 $\times$ C68 had the highest yields at 2.36 and 3.32 metric tons $\mathrm{ha}^{-1}$, respectively. P51 $\times$ P39 had the lightest dry weights ear $^{-1}$ in the 2010 and 2011 environments, respectively, at 39.6 and $84.8 \mathrm{~g}$. C68 $\times$ IL101t had the heaviest dry weight ear $^{-1}(96.1 \mathrm{~g})$ in the 2010 Arlington and West Madison environments, and Ia5125 $\times$ C40 had the heaviest dry weight ear ${ }^{-1}(122.8 \mathrm{~g})$ in the 2011 Arlington and West Madison environments. For ear length, the shortest ears in both years were found on P51 $\times$ P39 at $11.6 \mathrm{~cm}$ in 2010 and $14.0 \mathrm{~cm}$ in 2011 . The longest ears in both years were from hybrid IL101t $\times$ C40 at $15.5 \mathrm{~cm}$ in 2010 and $16.8 \mathrm{~cm}$ in 2011. P51 $\times$ P39 had the most shallow kernels in both years, at $4.4 \mathrm{~mm}$ in 2010 and $5.8 \mathrm{~mm}$ in 2011. In the 2010 Arlington and West Madison environments, Ia5125 × C68 had the largest kernel depth at $7.2 \mathrm{~mm}$. In the 2011 Arlington and West Madison environments, IL101t $\times$ Ia5125 had the largest kernel depth at $7.7 \mathrm{~mm}$.

Table 1. Significance of mean squares from analysis of variance for agronomic traits of 15 hybrids from a six line half-diallel measured in Arlington, WI and West Madison, WI in 2010 and 2011.

\begin{tabular}{|c|c|c|c|c|c|c|c|c|}
\hline \multirow[b]{2}{*}{ Trait } & \multirow[b]{2}{*}{ Environment } & \multicolumn{7}{|c|}{ Source of variation } \\
\hline & & Density & $\begin{array}{c}\text { Environment } \\
\times \text { Density }\end{array}$ & Hybrid & GCA & SCA & $\begin{array}{c}\text { Hybrid } \times \\
\text { Environment }\end{array}$ & $\begin{array}{c}\text { Hybrid } \\
\times \\
\text { Density }\end{array}$ \\
\hline Yield & $* * *$ & $* *$ & $* * *$ & $* * *$ & $* * *$ & $* * *$ & $* * *$ & $* * *$ \\
\hline Plant height & $* * *$ & $* *$ & ns & $* * *$ & $* * *$ & $* * *$ & $* * *$ & $* * *$ \\
\hline Ear height & $* * *$ & $* *$ & $*$ & $* * *$ & $* * *$ & $* * *$ & $* * *$ & $* *$ \\
\hline $\begin{array}{l}\text { Tiller } \\
\text { number }\end{array}$ & $* *$ & $* * *$ & ns & $* * *$ & $* * *$ & ns & $* *$ & * \\
\hline Wet weight & $* * *$ & $* * *$ & $* * *$ & $* * *$ & $* * *$ & $* * *$ & $* * *$ & $* * *$ \\
\hline Dry weight & $* * *$ & $* * *$ & $* *$ & $* * *$ & $* * *$ & $* * *$ & $* * *$ & $* * *$ \\
\hline Ear length & $* * *$ & $* * *$ & $* *$ & $* * *$ & $* * *$ & $* * *$ & $* * *$ & $* * *$ \\
\hline Ear width & $* * *$ & $* * *$ & ns & $* * *$ & $* * *$ & $* * *$ & $* * *$ & $* * *$ \\
\hline $\begin{array}{l}\text { Kernel } \\
\text { depth }\end{array}$ & $* * *$ & $* * *$ & ns & $* * *$ & $* * *$ & $* * *$ & $* * *$ & ns \\
\hline Moisture & $* * *$ & $*$ & $* *$ & $* * *$ & nc & nc & $* * *$ & $* * *$ \\
\hline Ears ha ${ }^{-1} \uparrow$ & $* * *$ & $* * *$ & $* *$ & $* *$ & nc & nc & $* * *$ & $* * *$ \\
\hline $\begin{array}{l}\text { Tip } \\
\text { blanking } \dagger\end{array}$ & $* * *$ & $* * *$ & $\mathrm{~ns}$ & $* * *$ & nc & nc & $* * *$ & $* * *$ \\
\hline
\end{tabular}

$*, * *, * * *$ Significant at $0.05,0.01$, and 0.001 probability levels, respectively; $\dagger$ Analysis based on ranks; $\mathrm{ns}=$ Non-significant, $\mathrm{nc}=$ not calculated. 
Table 2. Least square means for agronomic traits of 15 hybrids from a six line half-diallel measured in Arlington, WI and West Madison, WI in 2010 and 2011.

\begin{tabular}{lcccccc}
\hline Hybrid & $\begin{array}{c}\text { Plant height } \\
(\mathbf{c m})\end{array}$ & $\begin{array}{c}\text { Ear height } \\
(\mathbf{c m})\end{array}$ & Tiller \# & $\begin{array}{c}\text { Wet weight } \\
(\mathbf{g})\end{array}$ & $\begin{array}{c}\text { Ear width } \\
(\mathbf{m m})\end{array}$ & $\begin{array}{c}\text { Moisture } \\
(\mathbf{\%})\end{array}$ \\
\hline C40 $\times$ P39 & 224.33 & 90.30 & 2.61 & 212.54 & 37.92 & 53.04 \\
C40 $\times$ P51 & 219.41 & 89.82 & 2.40 & 191.54 & 36.06 & 55.68 \\
C68 $\times$ C40 & 251.68 & 108.51 & 1.56 & 247.71 & 39.44 & 58.92 \\
C68 $\times$ IL101t & 249.54 & 94.75 & 1.68 & 245.75 & 39.58 & 57.18 \\
C68 $\times$ P51 & 250.80 & 101.66 & 1.56 & 218.46 & 38.02 & 57.21 \\
Ia5125 $\times$ C40 & 246.48 & 106.83 & 1.39 & 234.32 & 41.52 & 53.26 \\
Ia5125 $\times$ C68 & 267.86 & 115.99 & 0.50 & 243.33 & 42.40 & 56.20 \\
Ia5125 × P51 & 234.50 & 99.21 & 1.25 & 187.67 & 39.90 & 49.30 \\
IL101t $\times$ Ia5125 & 231.67 & 86.46 & 1.39 & 170.17 & 39.52 & 45.11 \\
IL101t $\times$ C40 & 218.25 & 80.17 & 2.49 & 213.58 & 36.16 & 55.63 \\
P39 $\times$ C68 & 242.01 & 97.35 & 1.78 & 212.12 & 38.29 & 56.98 \\
P39 $\times$ Ia5125 & 225.80 & 94.29 & 1.48 & 165.29 & 38.98 & 48.44 \\
P39 $\times$ IL101t & 211.99 & 71.08 & 2.80 & 149.87 & 36.02 & 48.35 \\
P51 $\times$ IL101t & 212.50 & 75.31 & 2.63 & 164.29 & 36.13 & 49.21 \\
P51 $\times$ P39 & 207.40 & 82.82 & 2.63 & 126.54 & 33.79 & 49.07 \\
CV & 0.03 & 0.06 & 0.27 & 0.11 & 0.03 & 0.06 \\
LSD (0.05) & 6.33 & 4.65 & 0.27 & 38.77 & 1.56 & 5.81 \\
\hline
\end{tabular}

Table 3. Least square means for agronomic traits of 15 hybrids from a six line half-diallel, averaged across specified years in Arlington, WI and West Madison, WI.

\begin{tabular}{lcccccccc}
\hline & \multicolumn{2}{c}{ Yield } & \multicolumn{2}{c}{$\begin{array}{c}\text { Dry weight } \\
(\mathbf{m})\end{array}$} & \multicolumn{2}{c}{$\begin{array}{c}\text { Ear length } \\
(\mathbf{c m})\end{array}$} & \multicolumn{2}{c}{$\begin{array}{c}\text { Kernel size } \\
(\mathbf{m m})\end{array}$} \\
\hline Hybrid & 2010 & 2011 & 2010 & 2011 & 2010 & 2011 & 2010 & 2011 \\
\hline C40 $\times$ P39 & 1.90 & 2.70 & 87.25 & 109.17 & 13.67 & 16.18 & 6.71 & 6.63 \\
C40 $\times$ P51 & 1.78 & 2.78 & 69.42 & 99.33 & 13.67 & 15.19 & 6.21 & 6.08 \\
C68 $\times$ C40 & 2.15 & 3.26 & 89.00 & 115.58 & 13.96 & 15.45 & 6.67 & 6.77 \\
C68 $\times$ IL101t & 2.18 & 3.21 & 96.08 & 114.58 & 14.17 & 14.74 & 7.15 & 7.48 \\
C68 $\times$ P51 & 2.13 & 2.79 & 87.00 & 99.75 & 13.50 & 14.49 & 6.58 & 6.02 \\
Ia5125 $\times$ C40 & 2.29 & 3.11 & 93.42 & 122.75 & 14.16 & 15.49 & 7.05 & 7.49 \\
Ia5125 $\times$ C68 & 2.36 & 3.32 & 93.25 & 120.12 & 13.25 & 14.78 & 7.21 & 7.49 \\
Ia5125 $\times$ P51 & 1.90 & 3.31 & 64.42 & 114.50 & 13.53 & 14.76 & 5.65 & 7.27 \\
IL101t $\times$ Ia5125 & 1.32 & 2.91 & 57.50 & 117.17 & 13.22 & 14.90 & 6.00 & 7.71 \\
IL101t $\times$ C40 & 1.90 & 2.75 & 80.11 & 107.58 & 15.51 & 16.75 & 6.47 & 6.71 \\
P39 $\times$ C68 & 2.13 & 2.58 & 83.08 & 99.08 & 13.67 & 14.94 & 6.25 & 6.29 \\
P39 $\times$ Ia5125 & 0.99 & 2.88 & 50.50 & 109.00 & 12.62 & 14.80 & 5.17 & 7.19 \\
P39 $\times$ IL101t & 1.17 & 2.70 & 50.08 & 97.67 & 13.75 & 15.03 & 4.85 & 6.44 \\
P51 $\times$ IL101t & 1.67 & 2.93 & 63.67 & 98.42 & 13.89 & 14.92 & 5.81 & 6.46 \\
P51 $\times$ P39 & 0.86 & 2.41 & 39.58 & 84.83 & 11.63 & 14.00 & 4.38 & 5.83 \\
CV & 0.19 & 0.15 & 0.13 & 0.09 & 0.07 & 0.04 & 0.10 & 0.08 \\
LSD $(0.05)$ & 0.27 & 0.48 & 12.45 & 9.97 & 1.07 & 0.52 & 0.48 & 0.45 \\
\hline
\end{tabular}


Pearson correlation coefficients were generated for agronomic traits of interest from the means of the fifteen hybrids, pooled across all environments. Yield was found to be highly correlated $(p \leq 0.001)$ with plant height $(\mathrm{r}=0.83)$, and was also positively correlated with ear width $(\mathrm{r}=0.74)$, moisture $(\mathrm{r}=0.68)$, and total ears $\mathrm{ha}^{-1}(\mathrm{r}=0.64)$ (Table 4). Yield was negatively correlated with tiller number $(\mathrm{r}=-0.60)$. Plant height was highly correlated with ear width $(\mathrm{r}=0.85)$, correlated with moisture $(\mathrm{r}=0.59)$, and negatively correlated with tiller number $(\mathrm{r}=-0.86)$. Tiller number was also negatively correlated with ear width $(\mathrm{r}=-0.90)$. Finally, ear length was positively correlated with tip blanking $(\mathrm{r}=0.56)$.

GCA and SCA effects were analyzed for selected traits across all environments and all densities, as well as separately for each density. Data from analysis at the highest density is reported here. C68 had the largest GCA at the highest density for the following traits: plant height $(21.7 \mathrm{~cm})$, ear height $(12.3 \mathrm{~cm})$, wet weight $(35.7 \mathrm{~g})$, and dry weight $(8.1 \mathrm{~g})$ (Table 5). Both C68 and C40 had the largest GCA at the highest density for yield $\left(0.3\right.$ metric tons $\left.\mathrm{ha}^{-1}\right)$. C40 also had the largest GCA for ear length $(0.9 \mathrm{~cm})$. Ia5125 had the largest negative GCA for tiller number $(-0.8)$ at the highest density, as well as the widest ears $(2.1 \mathrm{~mm})$ and deepest kernels $(0.4 \mathrm{~mm})$. P39 had the greatest negative GCA at the highest density for yield $\left(-0.5\right.$ metric tons $\left.\mathrm{ha}^{-1}\right)$, plant height $(-15.5 \mathrm{~cm})$, wet weight $(-23.2 \mathrm{~g})$, dry weight $(-7.7 \mathrm{~g})$, ear width $(-1.4 \mathrm{~mm})$ and kernel depth $(-0.7 \mathrm{~mm})$. P39 also had the highest GCA for tiller number (0.5). Analysis of SCA showed few hybrids with significant effects, either averaged across all densities or separately at each density. The predictability of determining progeny performance using GCA ranged from 0.90 to 1.00 , based on the ratio of $2 \mathrm{MS}_{\mathrm{GCA}}$ to $2 \mathrm{MS}_{\mathrm{GCA}}+\mathrm{MS}_{\mathrm{SCA}}$ [25]. Ear length had the lowest predictability at 0.90, while ear height had the highest predictability at 1.00 (Table 6).

Table 4. Pearson correlation coefficients for selected agronomic traits from the means of 15 hybrids from a six line half-diallel measured in Arlington, WI and West Madison, WI in 2010 and 2011.

\begin{tabular}{cccccccc}
\hline Trait & $\begin{array}{c}\text { Ears } \\
\text { ha }^{-1}\end{array}$ & Moisture & $\begin{array}{c}\text { Plant } \\
\text { height }\end{array}$ & $\begin{array}{c}\text { Tiller } \\
\text { number }\end{array}$ & $\begin{array}{c}\text { Ear } \\
\text { length }\end{array}$ & $\begin{array}{c}\text { Ear } \\
\text { width }\end{array}$ & $\begin{array}{c}\text { Tip } \\
\text { blanking }\end{array}$ \\
\hline Yield & $0.64^{*}$ & $0.68^{* *}$ & $0.83^{* * *}$ & $-0.60^{*}$ & $\mathrm{~ns}$ & $0.74^{* *}$ & $\mathrm{~ns}$ \\
Ears ha $^{-1}$ & & $\mathrm{~ns}$ & $\mathrm{~ns}$ & $\mathrm{~ns}$ & $\mathrm{~ns}$ & $\mathrm{~ns}$ & $\mathrm{~ns}$ \\
Moisture & & & $0.59^{*}$ & $\mathrm{~ns}$ & $\mathrm{~ns}$ & $\mathrm{~ns}$ & $\mathrm{~ns}$ \\
Plant height & & & & $-0.86^{* * *}$ & $\mathrm{~ns}$ & $0.85^{* * *}$ & $\mathrm{~ns}$ \\
Tiller number & & & & & $\mathrm{ns}$ & $-0.90^{* * *}$ & $\mathrm{~ns}$ \\
Ear length & & & & & & $\mathrm{ns}$ & $0.56^{*}$ \\
Ear width & & & & & & & $\mathrm{ns}$ \\
\hline
\end{tabular}

$* * *, * * *$ Significant at $0.05,0.01$, and 0.001 probability levels, respectively. $\mathrm{ns}=$ non-significant. 
Table 5. General combining abilities for agronomic traits of 15 hybrids from a six line half-diallel measured at the highest density in Arlington, WI and West Madison, WI in 2010 and 2011.

\begin{tabular}{|c|c|c|c|c|c|c|c|c|c|}
\hline Inbred & $\begin{array}{c}\text { Yield } \\
(\text { metric } \\
\left.\text { tons ha }{ }^{-1}\right)\end{array}$ & $\begin{array}{c}\text { Plant } \\
\text { height } \\
(\mathrm{cm})\end{array}$ & $\begin{array}{c}\text { Ear } \\
\text { height } \\
(\mathrm{cm})\end{array}$ & $\begin{array}{c}\text { Tiller } \\
\#\end{array}$ & $\begin{array}{c}\text { Wet } \\
\text { weight } \\
\text { (g) }\end{array}$ & $\begin{array}{c}\text { Dry } \\
\text { weight } \\
\text { (g) } \\
\end{array}$ & $\begin{array}{c}\text { Ear } \\
\text { length } \\
(\mathrm{cm})\end{array}$ & $\begin{array}{c}\text { Ear } \\
\text { width } \\
(\mathbf{m m})\end{array}$ & $\begin{array}{c}\text { Kernel } \\
\text { depth } \\
(\mathrm{mm})\end{array}$ \\
\hline $\mathrm{C} 40$ & 0.3 & ns & ns & ns & 22.6 & 8.0 & 0.9 & $\mathrm{~ns}$ & 0.3 \\
\hline C68 & 0.3 & 21.7 & 12.3 & -0.5 & 35.7 & 8.1 & ns & 1.6 & 0.3 \\
\hline Ia5125 & ns & 14.8 & 12.1 & -0.8 & ns & ns & -0.5 & 2.1 & 0.4 \\
\hline IL101t & ns & -9.0 & -14.5 & 0.3 & -19.1 & -6.2 & $\mathrm{~ns}$ & -1.1 & $\mathrm{~ns}$ \\
\hline P39 & -0.5 & -15.5 & -7.8 & 0.5 & -23.2 & -7.7 & $\mathrm{~ns}$ & -1.4 & -0.7 \\
\hline P51 & $\mathrm{ns}$ & -9.6 & -4.9 & $\mathrm{~ns}$ & -12.8 & ns & $\mathrm{ns}$ & -1.3 & -0.4 \\
\hline $\operatorname{LSD}(0.05)$ & 0.2 & 4.9 & 3.7 & 0.3 & 11.4 & 5.1 & 0.5 & 0.7 & 0.3 \\
\hline
\end{tabular}

ns $=$ non-significant.

Table 6. Predictability of GCA for agronomic traits measured on 15 hybrids from a six line half-diallel in Arlington, WI and West Madison, WI in 2010 and 2011.

\begin{tabular}{cccc}
\hline Trait & Mean squares: GCA & Mean squares: SCA & Predictability' \\
\hline Yield & 1.04 & 0.12 & 0.96 \\
Plant height & 3450.31 & 64.00 & 0.99 \\
Ear height & 1739.41 & 12.47 & 1.00 \\
Tiller number & 5.07 & 0.01 & 0.99 \\
Wet weight & 14365.02 & 856.37 & 0.97 \\
Dry weight & 1572.82 & 174.07 & 0.95 \\
Ear length & 4.54 & 0.95 & 0.90 \\
Ear width & 55.15 & 2.96 & 0.97 \\
Kernel depth & 3.59 & 0.38 & 0.95 \\
\hline
\end{tabular}

$\dagger$ Ratio of $\left(2 * \mathrm{MS}_{\mathrm{GCA}}\right):\left(2 * \mathrm{MS}_{\mathrm{GCA}}+\mathrm{MS}_{\mathrm{SCA}}\right)$.

\subsection{General Discussion}

Similar to prior research, this experiment found that morphological traits and ear characteristics are affected by crop density $[13,22,26]$. Averaged across all hybrids, plant height and ear height increased with higher densities, while tiller number decreased (Figure 1). As expected, ear weight, ear length, and kernel depth decreased at higher densities, while tip blanking increased. Interestingly, although the total ears per hectare increased as the density increased, the overall yield, measured in metric tons per hectare and adjusted to $15.5 \%$ moisture, was highest at the mid density. These results suggest the importance of identifying inbred lines and hybrid combinations that maintain ear size at higher density plantings. 
Figure 1. Box and whisker plots for agronomic traits of 15 hybrids from a six line half-diallel measured in Arlington, WI and West Madison, WI in 2010 and 2011 at three plant densities $\left(1=29,936\right.$ plants ha ${ }^{-1}, 2=63,615$ plants ha ${ }^{-1}, 3=97,293$ plants ha $\left.{ }^{-1}\right)$. The box depicts the middle $50 \%$ of the data and the solid line within the box indicates the median. The whiskers extend to 1.5 times the interquartile range, and the open circles are data values beyond this range.

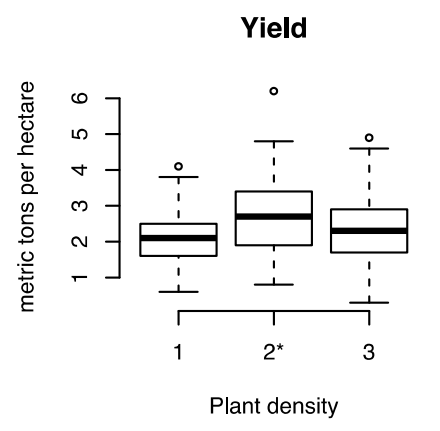

Tillering

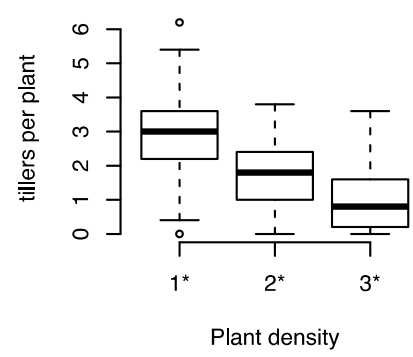

Kernel depth

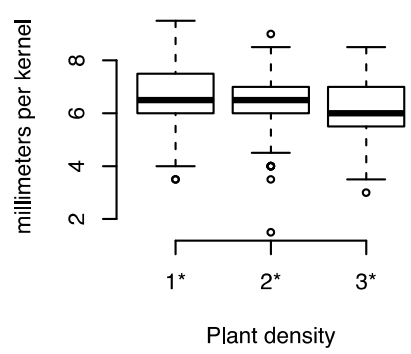

Plant height

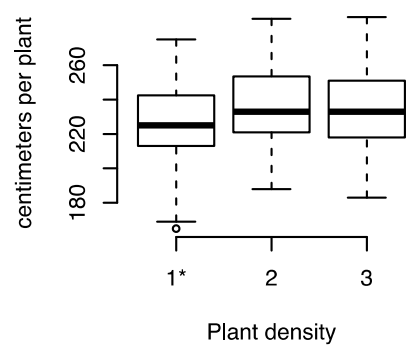

Ear dry weight

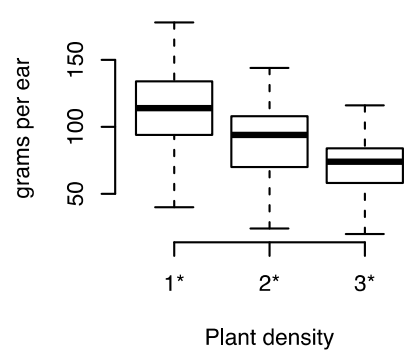

Tip blanking

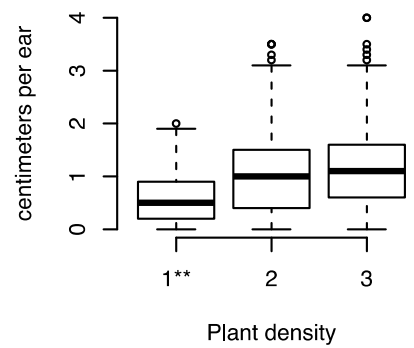

Ear height

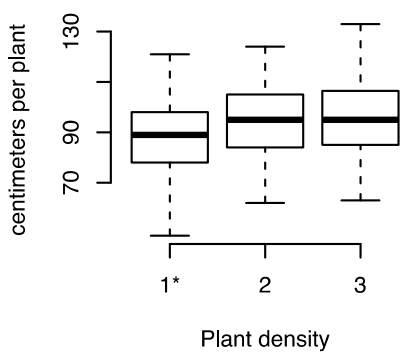

Ear length

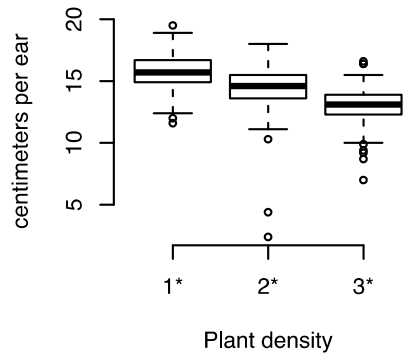

Total ears

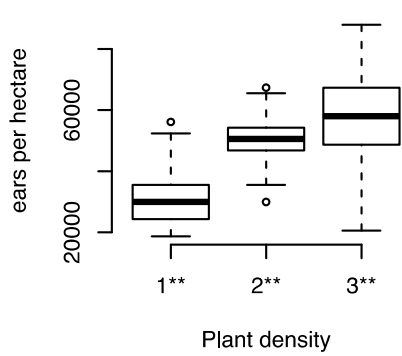

*Significant difference of means at $p \leq 0.05$ level; **Significant difference of means at $p \leq 0.01$ level.

Temperature and rainfall patterns may explain some of the genotype by environment rank change interactions observed in yield, dry weight, ear length and kernel depth responses. Year 2010 was wetter compared to 2011, with rainfall amounts throughout the entire growing season in 2010 almost double those of 2011. Temperature was less variable, although cumulative growing degree days were consistently higher in West Madison, WI compared to Arlington, WI for both years.

In a previous experiment, Zystro et al. [27] analyzed the effects of phenomorphological traits of the same inbred parents used in the present study on sweet corn weed competitiveness, and found plant height to be highly correlated with increased weed suppressive ability. In the present study, plant height was also highly correlated with yield and ear width (Table 4). In addition, plant height was 
correlated with moisture, suggesting that the taller plants may take longer to dry down and/or reach physiological maturity. While maturity was highly correlated with moisture $(p \leq 0.001)$ in the 2010 and 2011 West Madison, WI environments, plant height and maturity were not correlated (data not shown). Tiller number, on the other hand, was negatively correlated with plant height, yield and ear width, indicating that a tall plant with minimal tillers may be a desired phenotype for higher density tolerance. Correlation is not causation, however, and as noted by Zystro et al. [27], plant height and tiller number may be the observed trait that is linked to unmeasured factors increasing high density tolerance.

Zystro et al. [27] also used a similar diallel analysis, identifying C68 as the most competitive inbred due to its height and its production of hybrids with the highest yields and lowest weed biomass. Results from the present study further suggested the utility of C68 as a parental line to improve density tolerance and potential weed competitiveness in sweet corn. When grown at the highest density, C68 had the largest positive GCA effects for plant height, ear height, wet weight and dry weight (Table 5). It also shared the largest GCA effect at the highest density for yield along with C40 (Table 5). The wet weight advantage of $\mathrm{C} 68$ may be a factor of higher moisture content at harvest, as the five hybrids with the highest percent moisture all contained C68 as a parent (Table 2). However, when dried to constant moisture, the GCA effect of C68 remained the greatest (Table 5).

Another inbred to consider, given observed ear characteristics at the highest density, is C40. C40 had positive GCA effects for yield, wet weight, dry weight, kernel size, and the largest GCA effect for ear length. Ia5125 also performed well, with the highest GCA effects for ear width and kernel depth. Although it had a negative GCA effect for ear length, Ia5125 was found to have the second greatest GCA effect for plant height and ear height, and the most negative GCA effect for tiller number. In contrast, the performance of P39 suggests that it does not tolerate increased plant populations. At the highest density, P39 had the most negative GCA effects for yield, plant height, ear width, kernel depth, wet weight and dry weight (Table 5). P39 also had the greatest positive GCA effect for tiller number. These results also confirm Zystro et al.'s [27] finding that P39 was the least competitive.

At the highest density, significant SCA was rare for all traits. This indicates that the actual performance of each hybrid did not deviate from its expected performance, based on the mean of all hybrid combinations and the general combining ability of the inbred parents.

Predictability can be used as a measure to determine how relevant significant SCA mean squares are in determining hybrid performance [25]. When the ratio of mean squares of GCA to the total hybrid mean squares (mean squares of GCA and SCA) is close to one, then the predictability of traits can be based solely on GCA. The predictability of all traits analyzed in this experiment was quite high, ranging from 0.90-1.00, suggesting that GCA effects were better indicators than SCA effects of higher density tolerance (Table 6). Thus, based on GCA alone, this study concludes that C68, C40 and Ia5125 were useful inbred parents that could be used in future breeding programs to develop sweet corn tolerant to higher planting densities. In addition, inbred lines with tall plant heights, reduced tiller numbers, and wide ears may be more tolerant of higher planting densities.

At least two limitations of this study restrict the inferences that can be made and suggest areas of further research. First, because the inbred lines used in this study were specifically selected for their diverse morphologies, they do not represent a random sample of publicly available inbred sweet corn lines. Strictly speaking, the conclusions drawn cannot be extrapolated beyond the 6 inbred lines and 15 hybrids tested in this experiment. While some inferences can be made regarding the plant 
morphologies that may contribute to density tolerance, continued experimentation with modern inbreds may identify more parent lines useful to breeders working to improve density tolerance.

Second, the goal of this experiment was to provide useful information about the genetics of traits that confer high density tolerance to sweet corn, which may serve as a means of weed competitiveness for organic growers. It is important to note that density tolerance is also a useful trait for conventional growers. This experiment was conducted under conventional agronomic practices, and the results are applicable to both farming systems. However, as has been shown in previous studies, genotype by environment interactions can cause rank changes to occur in the performance of cultivars between conventional and organic systems [28,29]. While this study suggests inbred parents that have the potential to adapt to higher planting densities, lines identified for organic farming systems should be tested under organic conditions to evaluate their performance in the environment of intended use.

\section{Experimental Section}

\subsection{Germplasm}

Fifteen hybrids were used as experimental entries, formed from a six-line half diallel without parents based on Griffing's Model I, Method 4 [30]. Due to the large quantity of seed needed, hybrids used each year of the experiment (2010 and 2011) were produced the preceding year in a summer nursery (2009 and 2010). The six sugaryl (sul) inbred parents, available in the public domain, included: Ia5125, C40, C68, IL101t, P39, and P51. These inbred parents represent a diversity of sweet corn morphologies and backgrounds (Figure 2). According to Zyskowski [31], Ia5125 exhibits a horizontal leaf angle, while C68 and IL101t have vertical leaf angles. C40 has long, wide leaves in contrast to P39 with short, narrow leaves [31]. C68 is tall in stature, P39 has a short plant height, and P51 expresses many tillers [31].

Figure 2. Phylogeny of the inbred parents used in a six line half-diallel grown in Arlington, WI and West Madison, WI in 2010 and 2011 [32].

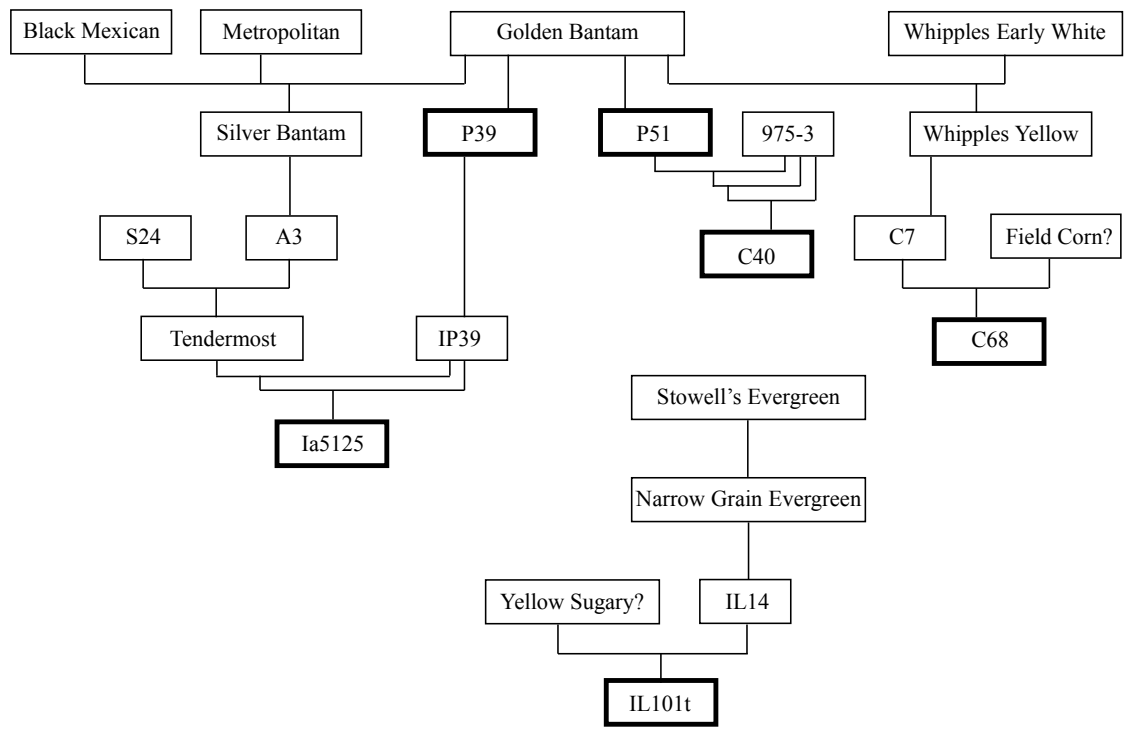




\subsection{Experimental Design}

The experiment was conducted in 2010 and 2011 at the University of Wisconsin's West Madison Agricultural Research Station $\left(43^{\circ} 04^{\prime} \mathrm{N}, 89^{\circ} 32^{\prime} \mathrm{W}\right)$ and Arlington Agricultural Research Station $\left(43^{\circ} 18^{\prime} \mathrm{N}, 89^{\circ} 21^{\prime} \mathrm{W}\right)$. Soil type at both locations is a Plano silt loam (fine-silty, mixed mesic Typic Argiudoll). The experiment was arranged as a split-block randomized complete block design (RCBD) with four replications per environment. The main-block factor was density and the sub-block factor was hybrid. Plots consisted of four rows, with each row measuring $3.5 \mathrm{~m}$ in length and spaced at a width of $0.76 \mathrm{~m}$. Alleys between plots measured $0.91 \mathrm{~m}$.

Sweet corn hybrids were planted at West Madison Agricultural Research Station on 01 June 2010 and 23 May 2011 and at Arlington Agricultural Research Station on 25 May 2010 and 31 May 2011. At the time of planting, the insecticide Force ${ }^{\circledR} 3 \mathrm{G}$ was applied at a rate of $4.93 \mathrm{~kg} \mathrm{ha}^{-1}$ in all four environments. The West Madison 2010 environment was sprayed with pre-emergence herbicides [Callisto ${ }^{\circledR}\left(0.35 \mathrm{~kg} \mathrm{ha}^{-1}\right)$, Dual II Magnum ${ }^{\circledR}\left(1.75 \mathrm{~L} \mathrm{ha}^{-1}\right)$, and Princep ${ }^{\circledR}\left(0.56 \mathrm{~kg} \mathrm{ha}^{-1}\right)$ ] on 02 June 2010. The same treatment was applied at Arlington on 27 May 2010 and 09 June 2011. The West Madison 2011 environment was sprayed with Dual II Magnum ${ }^{\circledR}\left(1.75 \mathrm{~L} \mathrm{ha}^{-1}\right)$ post-emergence, and hand-weeded throughout the season as needed. All plots were maintained weed-free for the duration of the experiment.

In each of the four environments, entries were over-planted by $50 \%$ and then subsequently thinned

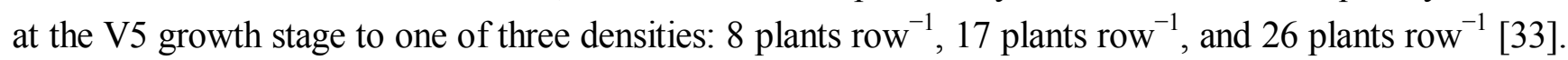
The resulting populations represented a low $\left(29,936\right.$ plants ha $\left.{ }^{-1}\right)$, medium $\left(63,615\right.$ plants ha $\left.{ }^{-1}\right)$ and high $\left(97,293\right.$ plants ha $\left.^{-1}\right)$ sweet corn density.

\subsection{Data Collection}

Phenomorphological data were collected during the 2010 and 2011 growing seasons for the fifteen experimental hybrids at the West Madison Agriculture Research Station (WM10, WM11) and the Arlington Agriculture Research Station (ARL10, ARL11). All data were taken from the first five bordered plants in the left-center row of the plot. Heat units, or growing degree days (GDD), were calculated from planting date by subtracting $10^{\circ} \mathrm{C}$ from the average daily temperature, with minimum temperatures set no lower than $10{ }^{\circ} \mathrm{C}$, and maximum temperatures set no higher than $30{ }^{\circ} \mathrm{C}$. Simultaneous measurements for late-season plant height, ear height, and tiller number were recorded post-anthesis (WM10: 762 GDD, 05 August 2010; ARL10: 726 GDD, 02 August 2010; WM11: 936 GDD, 08 August 2011; ARL11: 747 GDD, 10 August 2011). Plant height was measured as the distance from the soil surface to the tassel tip and ear height was measured as the distance from the soil surface to the ligule of the leaf subtending the uppermost ear.

Flowering dates were recorded for the WM10 and WM11 environments and used as a predictor of physiological maturity. Anthesis was recorded on the date when fifty percent of tassels in the center two rows of a plot had exerted fifty percent of their anthers. Likewise, silk emergence was recorded when fifty percent of the plants in the center two rows of a plot showed silk emergence from the husk.

To evaluate yield, all ears from bordered plants in the center two rows were harvested at physiological maturity, as determined by kernel black layer and flowering dates (WM10: 1172 GDD, 
14 September 2010 and 1185 GDD, 16 September 2010; ARL10: 1051 GDD, 31 August 2010 and 1062 GDD, 01 September 2010; WM11: 1249 GDD, 07 September 2011; ARL11: 1051 GDD, 14 September 2011). Data were collected on the total number of ears per plot and the total wet weight per plot. Ten ears were randomly selected from each plot, weighed, and then dried to constant moisture. The following yield components were measured on the ten randomly selected ears from each plot, dried to constant moisture: dry weight, ear length, ear width, and tip blanking (incomplete kernel development which leaves the tip of the ear barren). Kernel depth was determined by measuring the cob width [(ear width - cob width $) / 2$ ]. Ear moisture was calculated on a wet basis [(wet weight - dry weight)/wet weight]. Yield, measured as metric tons ha ${ }^{-1}$, was adjusted to a standard $15.5 \%$ moisture.

\subsection{Statistical Analysis}

For all traits measured, an analysis of variance (ANOVA) was calculated on plot means using PROC MIXED in the SAS 9.2 statistics package (SAS Institute, Cary, NC, USA). Density and hybrid were evaluated as fixed effects, while environment and replication within environment were considered random effects. Significant $(p \leq 0.05)$ hybrid-by-environment interactions were found for all traits, and thus means were pooled across environments if a Spearman rank correlation indicated that the effect was due to a change in magnitude but not in rank. Tests of the residuals for normality and equal variance were conducted prior to calculating mean squares. Non-normal data was not improved with logarithmic or square-root transformations. As a result, total ears $\mathrm{ha}^{-1}$ and tip blanking were analyzed based on ranks using PROC RANK in the SAS 9.2 statistics package (SAS Institute, Cary, NC, USA). Moisture was analyzed by accounting for the unequal variances between environments using the group statement in PROC MIXED. Means were compared using protected least significant differences (LSD) at $p$-value $\leq 0.05$ significance level. When hybrid effects were significant $(p \leq 0.05)$ for phenotypic traits of interest, correlations were determined using PROC CORR in SAS 9.2 (SAS Institute, Cary, NC, USA). General combining ability (GCA) and specific combining ability (SCA) of inbred parents was estimated for traits of interest in which the hybrid effect was significant $(p \leq 0.05)$ based on Griffing's Model I, Method 4 [30].

\section{Conclusions}

The purpose of this study was to examine the inheritance of traits associated with density tolerance for sweet corn. Planting sweet corn at higher densities may enable more effective canopy closure, reducing weed biomass through the increased light interception of the crop canopy [17,18]. However, higher planting densities can produce barren plants or small ears that are unsalable in varieties that have not been bred for higher density tolerance. The results of this experiment indicate that traits for higher density tolerance are present in publicly-available germplasm and can be used to breed sweet corn with increased density tolerance. Analysis of the ratio of GCA to SCA for plant morphology and ear traits suggest that parent performance in high density plantings can reliably predict offspring performance. In particular, publicly-available inbreds C68, C40 and Ia5125 could be utilized by sweet corn breeders to increase density tolerance. These results, taken in consideration with those of Zystro 
et al. [27], suggest the feasibility of breeding sweet corn for high density tolerance and increased weed competitiveness for organic systems.

\section{Acknowledgments}

This research was funded by the College of Agricultural and Life Sciences, University of Wisconsin-Madison.

\section{Conflict of Interest}

The authors declare no conflict of interest.

\section{References and Notes}

1. USDA-ERS. Organic Production; USDA-ERS: Washington, DC, USA, 2010.

2. Organic Trade Association. Organic Industry Survey; Organic Trade Association: Brattleboro, VT, USA, 2011.

3. Gomiero, T.; Pimentel, D.; Paoletti, M.G. Environmental impact of different agricultural management practices: conventional vs. organic agriculture. Crit. Rev. Plant Sci. 2011, 30, 95-124.

4. Nemecek, T.; Dubois, D.; Huguenin-Elie, O.; Gaillard, G. Life cycle assessment of Swiss farming systems: I. Integrated and organic farming. Agric. Syst. 2011, 104, 217-232.

5. Riemens, M.M.; Groeneveld, R.; Lotz, L.; Kropff, M. Effects of three management strategies on the seedbank, emergence and the need for hand weeding in organic arable cropping systems. Weed Res. 2007, 47, 442-451.

6. Liebman, M.; Davis, A.S. Integration of soil, crop and weed management in low-external-input farming systems. Weed Res. 2000, 40, 27-47.

7. Derksen, D.A.; Anderson, R.; Blackshaw, R.; Maxwell, B. Weed dynamics and management strategies for cropping systems in northern great plains. Agron. J. 2002, 94, 174-185.

8. Pester, T.A.; Burnside, O.; Orf, J. Increasing crop competitiveness to weeds through crop breeding. J. Crop. Prod. 1999, 2, 59-76.

9. Hiltbrunner, J.; Scherrer, C.; Streit, B.; Jeanneret, P.; Zihlmann, U.; Tschachtli, R. Long-term weed community dynamics in Swiss organic and integrated farming systems. Weed Res. 2008, 48, $360-369$.

10. USDA-NASS. Vegetables 2010 Summary; USDA-NASS: Washington, DC, USA, 2010.

11. Williams, M.M.; Rabaey, T.L.; Boerboom, C.M. Residual weeds of processing sweet corn in the north central regioin. Weed Technol. 2008, 22, 646-653.

12. So, Y.F.; Williams, M.M.; Pataky, J.K. Wild-proso millet differentially affects canopy architecture and yield components of 25 sweet corn hybrids. HortScience 2009, 44, 408-412.

13. Williams, M.M. Agronomics and economics of plant population density on processing sweet corn. Field Crop. Res. 2012, 128, 55-61.

14. Duvick, D.N. Genetic contributions to advances in yield of U.S. maize. Maydica 1992, 37, 69-79. 
15. Duvick, D.N.; Smith, J.S.C.; Cooper, M. Long-term selection in a commercial hybrid maize breeding program. In Plant Breeding Reviews; Janick, J., Ed.; John Wiley \& Sons: New York, NY, USA, 2004; Volume 24, Part 2, pp. 109-151.

16. Hammer, G.L.; Dong, Z.; McLean, G.; Doherty, A.; Messina, C.; Schussler, J.; Zinselmeier, C.; Paszkiewicz, S. Can changes in canopy and/or root system architecture explain historical yield trends in the U.S. corn belt? Crop Sci. 2009, 49, 299-312.

17. McLachlan, S.M.; Tollenaar, M.; Swanton, C.; Weise, S. Effect of corn-induced shading on dry matter accumulation, distribution, and architecture of redroot pigweed (Amaranthus retroflexus). Weed Sci. 1993, 41, 568-573.

18. Tollenaar, M.; Dibo, A.; Aguilera, A.; Weise, S.F.; Swanton, C.J. Effect of crop density on weed interference in maize. Agron. J. 1994, 86, 591-595.

19. Olsen, J.L.; Kristensen, L.; Weiner, J. Influence of sowing density and spatial pattern of spring wheat (Triticum aestivum) on the suppression of different weed species. Weed Biol. Manag. 2006, 6, 165-173.

20. Doll, H. The ability of barley to compete with weeds. Biol. Agric. Hortic. 1997, 14, 43-51.

21. Blackshaw, R.E. Safflower (Carthamus tinctorius) density and row spacing effects on competition with green foxtail (Setaria viridis). Weed Sci. 1993, 41, 403-408.

22. Mack, H.J. Effects of population density, plant arrangement, and fertilizers on yield of sweet corn. J. Am. Soc. Hortic. Sci. 1972, 97, 757-760.

23. Rogers, I.S.; Lomman, G.J. Effects of plant spacing on yield, size and kernel fill of sweet corn. Aust. J. Exp. Agr. 1988, 28, 787-792.

24. Sprague, G.F.; Tatum, L. General vs. specific combining ability in single crosses of corn. J. Am. Soc. Agron. 1942, 34, 923-932.

25. Baker, R.J. Issues in diallel analysis. Crop Sci. 1978, 18, 533-536.

26. Tetio-Kagho, F.; Gardner, F.P. Responses of maize to plant population density. I. Canopy development, light relationships, and vegetative growth. Agron. J. 1988, 80, 930-935.

27. Zystro, J.P.; de Leon, N.; Tracy, W.F. Analysis of traits related to weed competitiveness in sweet corn (Zea Mays L.). Sustainability 2012, 4, 543-560.

28. Murphy, K.; Campbell, K.; Lyon, S.; Jones, S. Evidence of varietal adaptation to organic farming systems. Field Crop. Res. 2007, 102, 172-177.

29. Reid, T.A.; Yang, R.; Salmon, D.F.; Navabi, A.; Spaner, D. Realized gains from selection for spring wheat grain yield are different in conventional and organically managed systems. Euphytica 2011, 177, 253-266.

30. Griffing, B. Concept of general and specific combining ability in relation to diallel crossing systems. Aust. J. Biol. Sci. 1956, 9, 463-493.

31. Zyskowski, J.P. Genetics of traits relating to weed competitiveness in sweet corn (Zea mays L.). Master's Thesis, University of Wisconsin, Madison, WI, USA, 2009.

32. Gerdes, J.T.; Behr, C.F.; Coors, J.G.; Tracy, W.F. Compilation of North American Maize Breeding Germplasm; Crop Science Society of America, Inc.: Madison, WI, USA, 1993. 
33. Ritchie, S.W.; Hanway, J.J.; Benson, G.O.; Herman, J.C. How a Corn Plant Develops; Iowa State University Cooperative Extension Service Special Report No. 48 (revised); Iowa State University of Sciences and Technology: Ames, IA, USA, 2003.

(C) 2013 by the authors; licensee MDPI, Basel, Switzerland. This article is an open access article distributed under the terms and conditions of the Creative Commons Attribution license (http://creativecommons.org/licenses/by/3.0/). 